\title{
Primary marginal zone B-cell lymphoma of the cavernous sinus: a case report and review of the literature
}

\author{
Cheng-Chun Yang ${ }^{1}$, Tai-Yuan Chen ${ }^{1,2}$, Yu-Kun Tsui ${ }^{1}$ and Ching-Chung Ko ${ }^{1,3^{*}}$ (0)
}

\begin{abstract}
Background: Primary lymphoma of the cavernous sinus is a rare form of extranodal non-Hodgkin lymphoma, of which very few cases have been reported in the published literature. This report presents the MRI findings with apparent diffusion coefficient (ADC) value in an exceedingly rare primary marginal zone B-cell lymphoma (MZBCL) of the cavernous sinus.

Case presentation: The case in this study is a 59-year-old immunocompetent male patient with a 2-month history of right ptosis and blurred vision. Right third cranial nerve palsy and binocular diplopia were observed upon neurological examination. Preoperative brain CT showed an extra-axial enhancing mass lesion in the right cavernous sinus. On MRI, ipsilateral internal carotid arterial encasement was noted without causing stenosis of the vessel. Isointense signal on T1-weighted and T2-weighted images, homogeneous contrast enhancement, and diffusion restriction were also observed. The mean ADC value of the tumor is $0.64 \times 10^{-3} \mathrm{~mm}^{2} / \mathrm{s}\left(\mathrm{b}\right.$ value $\left.=1000 \mathrm{~s} / \mathrm{mm}^{2}\right)$. Subtotal resection of the tumor was performed, and improvement of clinical symptoms were observed. The pathologic diagnosis of MZBCL was established by immunohistochemical examinations.
\end{abstract}

Conclusions: Primary MZBCL of the cavernous sinus is exceedingly rare, and preoperative confirmation poses a major challenge with $\mathrm{CT}$ and conventional MRI only. In this case, preoperative quantitative ADC value is shown to offer valuable additional information in the diagnostic process.

Keywords: CNS lymphoma, Marginal zone B-cell lymphoma, Cavernous sinus, MRI, DWI, ADC

\section{Background}

Primary central nervous system lymphoma (PCNSL) is a rare form of extranodal non-Hodgkin lymphoma (NHL) typically limited to the neuroaxis without systemic involvement. It represents approximately $1 \%$ of NHLs and $4 \%$ of all intracranial neoplasms $[1,2]$. The brain parenchyma is the most common site of involvement, followed by the eye, the leptomeninges, and the spinal cord [3]. Most PCNSLs are aggressive lymphomas

\footnotetext{
${ }^{*}$ Correspondence: kocc0729@gmail.com

1 Department of Medical Imaging, Chi Mei Medical Center, No. 901,

Zhonghua Rd., Yongkang Dist., Tainan City 710, Taiwan, ROC

Full list of author information is available at the end of the article
}

that typically affects immunocompromised patients and carry a dismal prognosis [3, 4]. Diffuse large B-cell lymphoma (DLBCL) is the most common histologic type, accounting for $90 \%$ of the cases [5]. The PCNSL usually presents as tumor mass located in the periventricular region of the brain parenchyma and exhibits pronounced contrast enhancement. Tumor necrosis with heterogeneous enhancement are more prevalent in the setting of immunocompromise [6]. However, PCNSL arising from the cavernous sinus is an extremely rare condition. The radiologic features of primary cavernous sinus lymphoma remain unclear owing to its rarity. This report details comprehensive preoperative CT and MRI findings with apparent diffusion coefficient (ADC) value in a case of 
primary marginal zone B-cell lymphoma (MZBCL) arising from the cavernous sinus. Published works pertaining to primary cavernous sinus lymphoma are also reviewed.

\section{Case presentation}

The case in this study is a 59-year-old male patient with unremarkable medical history and a 2-month duration of right ptosis and blurred vision. No headache, fever, weight loss or nocturnal sweating is documented. Neurological examination revealed palsy of the right third cranial nerve $(\mathrm{CN})$ and binocular diplopia. Pupillary light reflex and corneal reflex were intact. Routine laboratory data including complete blood count and urinalysis are within normal limits. Brain CT revealed an enhancing mass lesion in the right cavernous sinus (Fig. 1a) without surrounding skull bone destruction or hyperostosis (Fig. 1b). On brain MRI, an extra-axial tumor exhibiting isointense signals on T1-weighted and T2-weighted images and homogeneous contrast enhancement is observed (Fig. 1c, d). In addition, diffusion restriction is observed on diffusion-weighted imaging (DWI) with a low ADC value of $0.64 \times 10^{-3} \mathrm{~mm}^{2} / \mathrm{s}$ (b value $\left.=1000 \mathrm{~s} / \mathrm{mm}^{2}\right)($ Fig. 1e, f). The initial diagnoses made by the reporting neuroradiologist included meningioma, neurogenic tumor, and PCNSL. The patient underwent subtotal resection of the tumor via a right extended pterion approach. Intraoperatively, a soft and white tumor adhering to the wall of the cavernous sinus was identified, which was then meticulously resected without causing injury to the internal carotid artery (ICA). Histological examination revealed diffuse infiltration of the submitted specimen by small- to medium-sized lymphoid cells mixed with plasma cells (Fig. 1g). The final histopathologic diagnosis is MZBCL by immunohistochemical studies (Fig. 1h, i). A generalized systemic survey consisted of whole-body CT, positron emission tomography (PET) scan, and bone marrow biopsy. The results revealed no evidence of extracranial involvement. Clinical stage $\mathrm{I}_{\mathrm{E}}$ (extranodal disease limited to a single site) was thus designated according to the 2014 Lugano classification [7]. After surgery, the patient experienced relief of right ptosis and blurred vision. Adjuvant radiotherapy and chemotherapy were also implemented for residual tumor. Residual tumor and post-irradiation changes remained stable on follow-up MRI studies for more than 2 years (Fig. 1j).

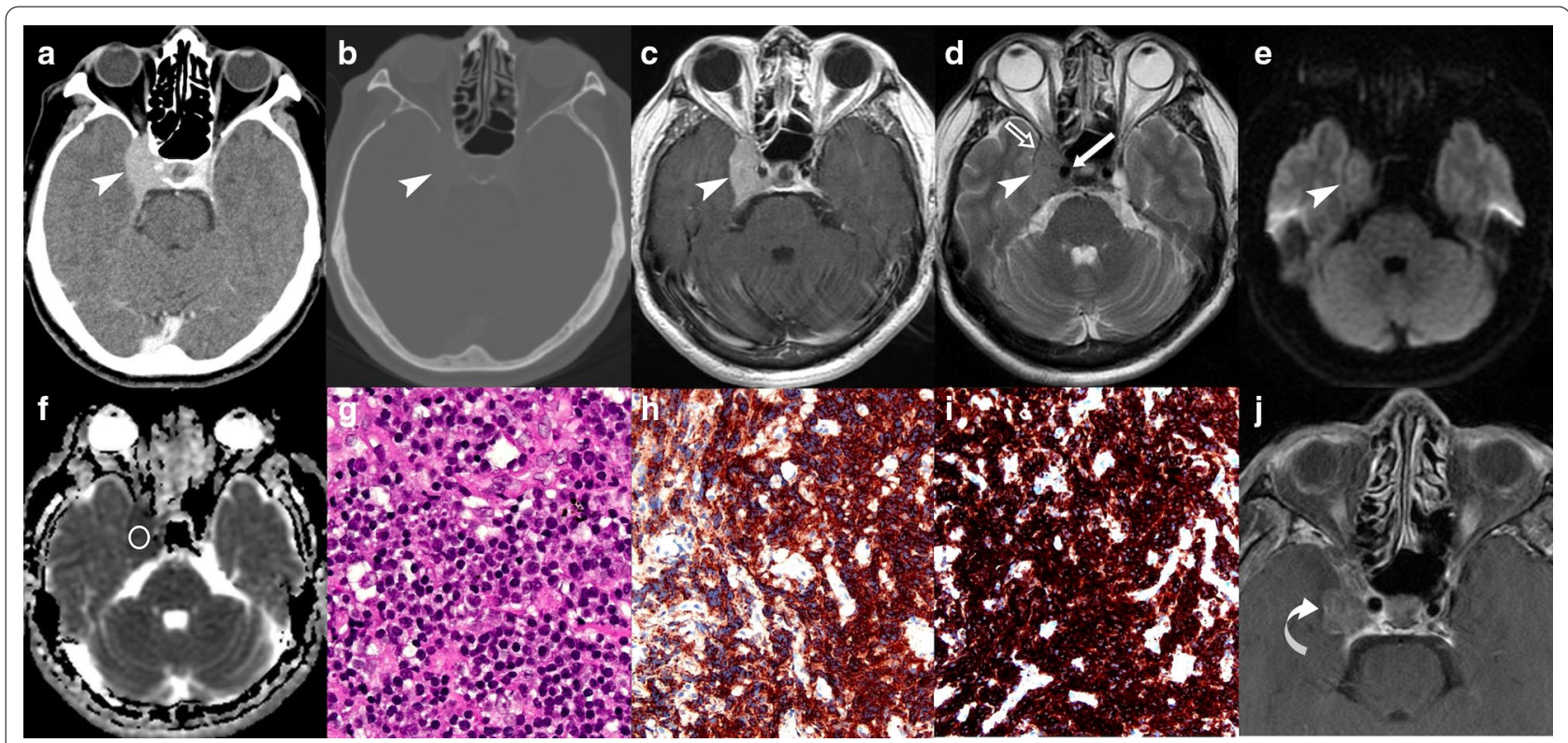

Fig. 1 A 59-year-old man with pathologically confirmed primary MZBCL of the right cavernous sinus. a Axial contrast-enhanced (CE) brain CT shows a bulging mass lesion (arrowhead) in the right cavernous sinus and measures $2.0 \times 3.3 \mathrm{~cm}$ in size. $\mathbf{b}$ Axial bone window $C T$ image revealed no surrounding skull bone destruction or hyperostosis around the tumor (arrowhead). c Axial CE T1WI shows homogeneous contrast enhancement of the tumor (arrowhead) after gadolinium administration. $\mathbf{d}$ The extra-axial origin of the tumor (arrowhead) is identified based on indentation of the right temporal dura (open arrow) on axial T2WI. In addition, encasement of ipsilateral cavernous internal carotid artery is observed without causing narrowing of the vascular lumen (white arrow). e Diffusion-weighted image (DWI) shows isointensity in the tumor (arrowhead). f The measured apparent diffusion coefficient (ADC) value (circular region of interest) is $0.64 \times 10^{-3} \mathrm{~mm}^{2} / \mathrm{s}\left(\mathrm{b}\right.$ value $=1000 \mathrm{~s} / \mathrm{mm}^{2}$ ), indicating diffusion restriction as compared with brain white matter. $\mathbf{g}$ The resected tumor is composed of a diffuse infiltration of small to median-sized lymphocytes mixed with plasma cells (h, e, $\times 200)$. h, i Positive staining for pan B cell markers including CD20 (h) and CD79a (i) on immunohistochemical examination (original magnification $\times 400$ ) are observed. $\mathbf{j}$ A stable residual mass with contrast enhancement (curved arrow) is observed on axial CE T1WI 2 years after surgical resection 


\section{Discussion and conclusions}

PCNSL arising from the cavernous sinus is a rare occurrence with only 21 known cases published in available literature in the English language. Amongst these cases, 8 are histologically confirmed MZBCL (Table 1). However, there have so far been no documented studies on preoperative comprehensive MRIs and ADC values in primary MZBCL of the cavernous sinus. The cavernous sinus can be involved by a myriad of diseases including neoplasms, vascular lesions, and infectious or inflammatory processes. In regards to neoplasms, the cavernous sinus is rarely involved by lymphoma, either primary or metastatic. Reported clinical symptoms of cavernous sinus lymphoma include visual disturbance, headache, ophthalmoplegia, cavernous sinus syndrome, or clinical features resembling trigeminal neuralgia and Tolosa-Hunt syndrome (Table 1).

MZBCL, a low-grade non-Hodgkin lymphoma derived from the postgerminal center, is best known for constituting the mucosal associated lymphoid tissue lymphoma (MALT lymphoma or MALToma) of the gastrointestinal tract associated with chronic infection of Helicobacter pylori [24]. In addition, recent studies had identified various autoimmune, chromosomal, and genetic factors to also be implicated in the pathogenesis of MZBCL [25]. CNS involvement of extranodal MZBCL is uncommon, and when it occurs, the most commonly involved structure is the dura ( $80 \%$ of the cases), followed by the brain parenchyma and other sites [26]. Radiologically, the disease typically presents as a dural-based mass, a feature rendering it easily mistaken for meningioma [27]. The pathogenesis of primary dural MZBCL is unclear, since the dura is devoid of organized lymphoid tissue. Some authors hypothesized that MZBCL may arise from meningothelial cells, which are tasked with the immunological protection of the brain from bacterial infection $[28,29]$. Likewise, the cavernous sinus also contains dura matter and can, at least theoretically, be involved by MZBCL, as is the case in our report. On the other hand, MZBCL is the most common histologic subtype (up to $75 \%$ ) in ocular adnexal lymphoma [30].

Common differential diagnoses of cavernous tumors include meningioma, schwannoma, metastasis, TolosaHunt syndrome, and hemangioma. From a radiological point of view, differentiation amongst these lesions can be challenging with conventional MRI only, since all may exhibit similar signal intensities and enhancement patterns. However, ADC values may offer additional diagnostic value in differentiating these lesions. In PCNSLs, diffusion restriction with low ADC values between $0.63 \times 10^{-3}$ and $0.71 \times 10^{-3} \mathrm{~mm}^{2} / \mathrm{s}$ have been reported [10, 31, 32]. De la Fuente et al. [8] have reported the median ADC value of $0.598 \times 10^{-3} \mathrm{~mm}^{2} / \mathrm{s}$ in six dural
MZBCL cases. Although the final diagnosis of MZBCL of the cavernous sinus needs to be confirmed by immunohistochemistry, the preoperative quantitative low ADC value $\left(0.64 \times 10^{-3} \mathrm{~mm}^{2} / \mathrm{s}\right)$ in our case offers valuable additional information in the diagnostic process. On conventional MRI, ICA encasement with vascular stenosis is characteristically present in the case of cavernous sinus meningiomas [33]. In contrast, patent ICA vascular lumen without narrowing is observed in our case. Most meningiomas are benign tumors and typically do not exhibit diffusion restriction on DWI [34]. Although rare high-grade (atypical and malignant) meningiomas may sometimes demonstrate diffusion restriction, higher ADC values of $0.78 \times 10^{-3} \mathrm{~mm}^{2} / \mathrm{s}$ to $0.8 \times 10^{-3} \mathrm{~mm}^{2} / \mathrm{s}$ had been reported in these high-grade meningiomas as compared with our case [35]. Furthermore, occurrence of high-grade meningiomas arising from the cavernous sinus has never been reported. Similarly, most of the nerve sheath tumors arising from the traversing cranial nerves or sympathetic plexus are benign neoplasms that do not exhibit diffusion restriction [36]. Metastases to the cavernous sinus can be more readily recognized based on a known clinical history of cancer, which may occur via direct invasion, perineural spread from the adjacent nasopharynx and bone, or hematogenous spread. Head and neck cancers are the most commonly identified culprits; rare instances of distant metastases from lung, breast and prostate malignancies have also been reported [37]. Tolosa-Hunt syndrome is essentially a clinical diagnosis of exclusion. It describes an idiopathic inflammatory process characterized by painful ophthalmoplegia secondary to inflammation surrounding the cavernous sinus. The usual presentation is that of an enhancing soft tissue lesion involving both the orbital apex and cavernous sinus, features different from those observed in our case [38]. Hemangiomas are rare vascular lesions involving the cavernous sinus which, similar to those occurring elsewhere, exhibit marked hyperintensity on T2WI and progressive contrast filling (centripetal enhancement) on dynamic contrast-enhanced T1WI [39]. In our case, theses differential diagnoses can be excluded in sequence by clinical history and MRI findings. Because MZBCL is extremely radiosensitive, regional treatment consisting of focal resection followed by radiotherapy has been shown to achieve complete response in most cases of dural MZBCL $[3,5]$. Therefore, preoperative recognition of this rare entity makes it possible to avoid unnecessarily aggressive surgical intervention.

To the best of our knowledge, this report is the first to mention and discuss preoperative ADC values of the primary cavernous sinus MZBCL. This case suggests that the combination of preoperative MRI and ADC values may offer helpful additional information 
Table 1 Primary central nervous system lymphoma of the cavernous sinus in published studies

\begin{tabular}{|c|c|c|c|c|c|c|c|c|c|}
\hline References & Age/sex & $\begin{array}{l}\text { Immune } \\
\text { status }\end{array}$ & $\begin{array}{l}\text { Histologic } \\
\text { type }\end{array}$ & Symptoms & $\begin{array}{l}\text { Involvement } \\
\text { site }\end{array}$ & Treatment & CT/MRI & DWI/ADC & Out-come \\
\hline \multirow{4}{*}{$\begin{array}{l}\text { de la Fuente } \\
\text { et al. [8] }\end{array}$} & $30 \mathrm{~F}$ & HIV $(-)$ & MZBCL & Facial pain & $\mathrm{CS}$ & Surgery, $R / T$ & $-1-$ & N/A & $C R$ \\
\hline & $51 \mathrm{~F}$ & HIV (-) & MZBCL & $\begin{array}{c}\text { Focal pares- } \\
\text { thesia and } \\
\text { numbness }\end{array}$ & Left CS & $C / T, R / T$ & $-1-$ & N/A & $C R$ \\
\hline & $48 \mathrm{~F}$ & $\operatorname{HIV}(-)$ & MZBCL & $\begin{array}{l}\text { Cranial nerve } \\
\text { palsy }\end{array}$ & Bilateral CS & $\mathrm{C} / \mathrm{T}$ & $-/-$ & N/A & $C R$ \\
\hline & $50 \mathrm{~F}$ & $\operatorname{HIV}(-)$ & $\mathrm{MZBCL}$ & $\begin{array}{l}\text { Cranial nerve } \\
\text { palsy }\end{array}$ & CS & Surgery, $R / T$ & $-/-$ & N/A & $C R$ \\
\hline Suresh et al. [9] & $24 \mathrm{~F}$ & N/A & $\mathrm{MZBCL}$ & $\begin{array}{l}\text { Right painless } \\
\text { vision loss, } \\
\text { bitemporal } \\
\text { visual field } \\
\text { defect }\end{array}$ & $\begin{array}{l}\text { Left CS, falx, } \\
\text { tentorium }\end{array}$ & Surgery, $C / T$ & $-/+$ & N/A & N/A \\
\hline $\begin{array}{l}\text { Dultra et al. } \\
\text { [10] }\end{array}$ & $63 \mathrm{M}$ & HIV (-) & $\begin{array}{l}\text { NHK B cell } \\
\text { lymphoma }\end{array}$ & $\begin{array}{l}\text { Frontal head- } \\
\text { ache, right } \\
\text { facial pain, } \\
\text { diplopia }\end{array}$ & $\begin{array}{l}\text { Bilateral CS, } \\
\text { sella }\end{array}$ & Surgery, $R / T$ & $-/+$ & N/A & $C R$ \\
\hline Ko et al. [11] & $70 \mathrm{~F}$ & N/A & DLBCL & $\begin{array}{l}\text { Facial pain, } \\
\text { complete } \\
\text { right ptosis, } \\
\text { diplopia }\end{array}$ & $\begin{array}{l}\text { Right CS, right } \\
\text { orbit }\end{array}$ & $\mathrm{C} / \mathrm{T}$ & $-/+$ & N/A & $C R$ \\
\hline $\begin{array}{l}\text { Demirkaya } \\
\text { et al. [12] }\end{array}$ & $4 \mathrm{M}$ & $\mathrm{N} / \mathrm{A}$ & NHK & $\begin{array}{l}\text { Right ptosis, } \\
\text { pupil } \\
\text { dilatation, } \\
\text { ophthalmo- } \\
\text { plegia }\end{array}$ & Right CS & Surgery, $C / T$ & $-/+$ & N/A & $C R$ \\
\hline $\begin{array}{l}\text { Sadruddin } \\
\text { et al. [13] }\end{array}$ & $17 \mathrm{~F}$ & N/A & TLBL & $\begin{array}{l}\text { Rapidly pro- } \\
\text { gressive right } \\
\text { headache, } \\
\text { diplopia, } \\
\text { facial numb- } \\
\text { ness }\end{array}$ & Right CS & $\begin{array}{l}\text { Surgery, } C / T \text {, } \\
R / T\end{array}$ & $-/+$ & N/A & $C R$ \\
\hline $\begin{array}{l}\text { Famoso et al. } \\
{[14]}\end{array}$ & $46 \mathrm{~F}$ & $\begin{array}{l}\text { Immuno- } \\
\text { competent }\end{array}$ & MZBCL & $\begin{array}{l}\text { Right exoph- } \\
\text { thalmos, } \\
\text { ptosis, retro- } \\
\text { orbital pain }\end{array}$ & $\begin{array}{l}\text { Right CS, } \\
\text { sella, orbital } \\
\text { meninges }\end{array}$ & $\begin{array}{l}\text { Surgery, rituxi- } \\
\text { mab }\end{array}$ & $-1-$ & N/A & $P R$ \\
\hline $\begin{array}{c}\text { Razaq et al. } \\
\text { [15] }\end{array}$ & $61 \mathrm{~F}$ & HIV $(-)$ & MZBCL & $\begin{array}{l}\text { Headache, CN } \\
\text { III palsy }\end{array}$ & $\begin{array}{l}\text { Left CS, left } \\
\text { optic nerve }\end{array}$ & $\mathrm{R} / \mathrm{T}$, rituximab & $-1-$ & N/A & $C R$ \\
\hline Choi et al. [16] & $12 \mathrm{M}$ & N/A & DLBCL & $\begin{array}{l}\text { Visual dis- } \\
\text { turbance, } \\
\text { periorbital } \\
\text { pain }\end{array}$ & $\begin{array}{l}\text { Bilateral CS, } \\
\text { dura, sphe- } \\
\text { noid bone }\end{array}$ & $\mathrm{C} / \mathrm{T}$ & $+/+$ & N/A & $C R$ \\
\hline $\begin{array}{l}\text { Nakamura } \\
\text { et al. [17] }\end{array}$ & $69 M$ & N/A & $\begin{array}{l}\text { *highly malig- } \\
\text { nant B cell } \\
\text { lymphoma }\end{array}$ & $\begin{array}{l}\text { Diplopia, } \\
\text { left facial } \\
\text { numbness, } \\
\text { dysarthria, } \\
\text { dysphagia } \\
\text { (Garcin } \\
\text { syndrome) }\end{array}$ & $\begin{array}{l}\text { Left CS, occipi- } \\
\text { tal and clival } \\
\text { bone }\end{array}$ & N/A & $-1+$ & N/A & N/A \\
\hline $\begin{array}{l}\text { Ronson et al. } \\
\text { [18] }\end{array}$ & $53 \mathrm{~F}$ & N/A & DLBCL & $\begin{array}{l}\text { Diplopia, } \\
\text { headache, } \\
\text { left mouth } \\
\text { paresthesia }\end{array}$ & $\begin{array}{l}\text { Right CS, right } \\
\text { sphenoid } \\
\text { sinus exten- } \\
\text { sion }\end{array}$ & $\begin{array}{l}\text { Surgery, } C / T \text {, } \\
R / T\end{array}$ & $-1-$ & $\mathrm{N} / \mathrm{A}$ & N/A \\
\hline $\begin{array}{l}\text { Sanjeevi et al. } \\
\text { [19] }\end{array}$ & $46 \mathrm{~F}$ & HIV $(-)$ & MZBCL & $\begin{array}{l}\text { Left side head- } \\
\text { ache, oph- } \\
\text { thalmalgia, } \\
\text { decreased } \\
\text { visual acuity }\end{array}$ & $\begin{array}{l}\text { Left CS, left } \\
\text { orbital apex }\end{array}$ & Surgery, $R / T$ & $-/+$ & N/A & $C R$ \\
\hline
\end{tabular}


Table 1 (continued)

\begin{tabular}{|c|c|c|c|c|c|c|c|c|c|}
\hline References & Age/sex & $\begin{array}{l}\text { Immune } \\
\text { status }\end{array}$ & $\begin{array}{l}\text { Histologic } \\
\text { type }\end{array}$ & Symptoms & $\begin{array}{l}\text { Involvement } \\
\text { site }\end{array}$ & Treatment & CT/MRI & DWI/ADC & Out-come \\
\hline $\begin{array}{l}\text { Arimoto et al. } \\
\text { [20] }\end{array}$ & $59 F$ & HIV (-) & $\begin{array}{l}\text { *diffuse small } \\
\text { B cell lym- } \\
\text { phoma }\end{array}$ & $\begin{array}{l}\text { Diplopia on } \\
\text { right lateral } \\
\text { gaze, right } \\
\text { facial hypes- } \\
\text { thesia }\end{array}$ & Right CS & Surgery, $\mathrm{R} / \mathrm{T}$ & $-/+$ & $\mathrm{N} / \mathrm{A}$ & $C R$ \\
\hline $\begin{array}{l}\text { Jaiswal et al. } \\
\text { [21] }\end{array}$ & $40 M$ & HIV (-) & DLBCL & $\begin{array}{l}\text { Right sided } \\
\text { headache, } \\
\text { tinnitus, } \\
\text { hearing } \\
\text { impairment, } \\
\text { ataxia }\end{array}$ & $\begin{array}{l}\text { Right CPA, } \\
\text { right CS, } \\
\text { right orbit }\end{array}$ & $\begin{array}{l}\text { Surgery, } C / T \text {, } \\
R / T\end{array}$ & $+/+$ & N/A & $C R$ \\
\hline \multirow[t]{3}{*}{$\begin{array}{l}\text { Roman-Gold- } \\
\text { stein et al. } \\
{[22]}\end{array}$} & $37 \mathrm{M}$ & $\begin{array}{l}\text { Immuno- } \\
\text { competent }\end{array}$ & $\mathrm{N} / \mathrm{A}$ & $\begin{array}{l}\text { Retro-orbital } \\
\text { headache, } \\
\text { diplopia }\end{array}$ & Right CS & $\mathrm{C} / \mathrm{T}$ & $-/+$ & $\mathrm{N} / \mathrm{A}$ & $C R$ \\
\hline & $62 M$ & $\begin{array}{l}\text { Immuno- } \\
\text { competent }\end{array}$ & $\mathrm{N} / \mathrm{A}$ & $\begin{array}{c}\text { Headache, } \\
\text { diplopia }\end{array}$ & Left CS & $\begin{array}{l}\text { Surgery, } C / T \text {, } \\
\mathrm{R} / \mathrm{T}\end{array}$ & $-/-$ & $\mathrm{N} / \mathrm{A}$ & $\begin{array}{l}\text { Died at } \\
18 \text { month }\end{array}$ \\
\hline & $51 \mathrm{~F}$ & $\begin{array}{l}\text { Immuno- } \\
\text { competent }\end{array}$ & $\mathrm{N} / \mathrm{A}$ & Diplopia & Left CS & Surgery, $\mathrm{C} / \mathrm{T}$ & $-/-$ & $\mathrm{N} / \mathrm{A}$ & $\mathrm{N} / \mathrm{A}$ \\
\hline $\begin{array}{l}\text { Nakatomi et al. } \\
\text { [23] }\end{array}$ & $77 \mathrm{M}$ & HIV (-) & DLBCL & $\begin{array}{l}\text { Left facial } \\
\text { hypesthesia, } \\
\text { diplopia }\end{array}$ & $\begin{array}{l}\text { Left CS, petro- } \\
\text { clival dura }\end{array}$ & $\begin{array}{l}\text { Surgery, } C / T \text {, } \\
R / T\end{array}$ & $-/+$ & N/A & $\begin{array}{l}\text { Died at } \\
31 \text { month }\end{array}$ \\
\hline
\end{tabular}

*Pathologic diagnoses not applicable to WHO 2016 classification, CPA, cerebellopontine angle; CS, cavernous sinus; CR, complete response; C/T, chemotherapy; DLBCL, diffuse large B-cell lymphoma; HIV, human immunodeficiency virus; N/A, not available; NHK, non-Hodgkin lymphoma; PR, partial response; R/T, radiotherapy; TLBL, T-cell acute lymphoblastic lymphoma

regarding to the diagnosis and treatment planning for lymphoma of the cavernous sinus.

\section{Abbreviations \\ ADC: Apparent diffusion coefficient; DLBCL: Diffuse large B-cell lymphoma; DWI: Diffusion-weighted image; MZBCL: Marginal zone B-cell lymphoma; PCNSL: Primary CNS lymphoma; PET: Positron emission tomography; T1WI: T1-weighted image;T2WI:T2-weighted image.}

\section{Acknowledgements}

Not applicable.

\section{Authors' contributions}

Conceived and designed the experiments: CCK. Analyzed the data: CCY YKT CCK. Wrote the paper: CCY CCK. Critically revised the article: TYC CCK. All authors read and approved the final manuscript.

\section{Funding}

This work was supported by the Chi Mei Medical Center/Chia Nan University of Pharmacy and Science, Tainan, Taiwan. The funders had no role in study design, data collection and analysis, decision to publish, or preparation of the manuscript.

\section{Availability of data and materials}

All data generated or analyzed in this study are included in this published article.

\section{Ethics approval and consent to participate}

This study was approved by the Institutional Review Board (IRB no.: 10902-009) of Chi Mei Medical Center. Written consent was waived because the retrospective nature of this study.

\section{Consent for publication}

Written consent was waived because the retrospective nature of this study meant that healthcare of included subject was not affected. The personal information was anonymized and de-identified.

\section{Competing interests}

The authors hereby declare that they have no competing interests.

\section{Author details}

${ }^{1}$ Department of Medical Imaging, Chi Mei Medical Center, No. 901, Zhonghua Rd., Yongkang Dist., Tainan City 710, Taiwan, ROC. ${ }^{2}$ Graduate Institute of Medical Sciences, Chang Jung Christian University, Tainan, Taiwan. ${ }^{3}$ Department of Health and Nutrition, Chia Nan University of Pharmacy and Science, Tainan, Taiwan.

Received: 25 September 2020 Revised: 28 January 2021 Accepted: 1 February 2021

Published online: 12 February 2021

\section{References}

1. O'Neill BP, Illig JJ. Primary central nervous system lymphoma. Mayo Clin Proc. 1989;64(8):1005-20

2. Hoffman S, Propp JM, McCarthy BJ. Temporal trends in incidence of primary brain tumors in the United States, 1985-1999. Neuro Oncol. 2006:8(1):27-37.

3. Villano JL, Koshy M, Shaikh H, Dolecek TA, McCarthy BJ. Age, gender, and racial differences in incidence and survival in primary CNS lymphoma. Br J Cancer. 2011;105(9):1414-8.

4. Iwamoto FM, Abrey LE. Primary dural lymphomas: a review. Neurosurg Focus. 2006:21(5):E5. 
5. Grommes C, DeAngelis LM. Primary CNS lymphoma. J Clin Oncol. 2017:35(21):2410-8.

6. Haldorsen IS, Espeland A, Larsson EM. Central nervous system lymphoma: characteristic findings on traditional and advanced imaging. AJNR Am J Neuroradiol. 2011;32(6):984-92.

7. Cheson BD, Fisher RI, Barrington SF, Cavalli F, Schwartz LH, Zucca E, et al. Recommendations for initial evaluation, staging, and response assessment of Hodgkin and non-Hodgkin lymphoma: the Lugano classification. J Clin Oncol. 2014:32(27):3059-68.

8. de la Fuente MI, Haggiagi A, Moul A, Young RJ, Sidani C, Markoe A, et al. Marginal zone dural lymphoma: the Memorial Sloan Kettering Cancer Center and University of Miami experiences. Leuk Lymphoma. 2017:58(4):882-8.

9. Suresh S, Abel AS, Younge BR, Bilyk JR, Lee MS. Masses in the membranes. Surv Ophthalmol. 2016;61(3):357-62.

10. Dultra AH, Noro F, de Melo AS, Landeiro JA, Marchiori E, do Nascimento MF. Primary intercavernous lymphoma of the central nervous system. Radiol Bras. 2015;48(5):337-8.

11. Ko F, Subramanian PS. Orbital and cavernous sinus lymphoma masquerading as post-herpetic neuralgia. Neuroophthalmology. 2011;35(1):27-31.

12. Demirkaya M, Sevinir B, Ozdemir O, Nazlioglu HO, Okan M. Lymphoma of the cavernous sinus mimicking Tolosa-Hunt syndrome in a child. Pediatr Neurol. 2010;42(5):351-4.

13. Sadruddin S, Medeiros $\sqcup$, DeMonte F. Primary T-cell lymphoblastic lymphoma of the cavernous sinus. J Neurosurg Pediatr. 2010;5(1):94-7.

14. Famoso G, Ponzoni M, Terreni MR, Assanelli A, Mortini P, Doglioni C, et al. Primary intracranial meningeal marginal zone B cell lymphoma of malt type (PMML) with osseous infiltration. Ann Hematol. 2009;88(6):599-601.

15. Razaq W, Goel A, Amin A, Grossbard ML. Primary central nervous system mucosa-associated lymphoid tissue lymphoma: case report and literature review. Clin Lymphoma Myeloma. 2009:9(3):E5-9.

16. Choi HK, Cheon JE, Kim IO, Youn BJ, Jung AY, Shin SM, et al. Central skull base lymphoma in children: MR and CT features. Pediatr Radiol. 2008;38(8):863-7.

17. Nakamura A, Toyoda K, Shozawa Y, Saito-Arai Y, Shimizu T, Matsumura K. Primary non-Hodgkin lymphoma of the skull base presenting with Garcin syndrome: MRI manifestations. J Neuroimaging. 2009;19(3):295-7.

18. Ronson B, Rossi C, Johnson S, Berdeja A, Slater JM, Slater JD. Locoregional proton radiotherapy of a primary cavernous sinus non-Hodgkin's lymphoma: case report. Technol Cancer Res Treat. 2006;5(3):281-4.

19. Sanjeevi A, Krishnan J, Bailey PR, Catlett J. Extranodal marginal zone B-cell lymphoma of malt type involving the cavernous sinus. Leuk Lymphoma. 2001;42(5):1133-7.

20. Arimoto H, Shirotani T, Nakau H, Hashizume K, Sakai Y, Matsukuma S. Primary malignant lymphoma of the cavernous sinus-case report. Neurol Med Chir (Tokyo). 2000;40(5):275-9.

21. Jaiswal AK, Tripathi M, Chandra PS, Sharma MC, Mahapatra AK. An unusual case of primary lymphoma of the skull base extending from cerebellopontine angle to cavernous sinus and orbit. A case report. J Neurosurg Sci. 2000;44(3):145-8.

22. Roman-Goldstein SM, Jones A, Delashaw JB, McMenomey S, Neuwelt EA Atypical central nervous system lymphoma at the cranial base: report of four cases. Neurosurgery. 1998;43(3):613-5.

23. Nakatomi H, Sasaki T, Kawamoto S, Fujimaki T, Furuya K, Kirino T. Primary cavernous sinus malignant lymphoma treated by gamma knife radiosurgery: case report and review of the literature. Surg Neurol. 1996;46(3):272-8
24. Farinha P, Gascoyne RD. Helicobacter pylori and MALT lymphoma. Gastroenterology. 2005;128(6):1579-605.

25. Zucca E, Bertoni F, Vannata B, Cavalli F. Emerging role of infectious etiologies in the pathogenesis of marginal zone B-cell lymphomas. Clin Cancer Res. 2014;20(20):5207-16.

26. Ayanambakkam A, Ibrahimi S, Bilal K, Cherry MA. Extranodal marginal zone lymphoma of the central nervous system. Clin Lymphoma Myeloma Leuk. 2018;18(1):34-7.

27. Tu PH, Giannini C, Judkins AR, Schwalb JM, Burack R, O'Neill BP, et al. Clinicopathologic and genetic profile of intracranial marginal zone lymphoma: a primary low-grade CNS lymphoma that mimics meningioma. J Clin Oncol. 2005;23(24):5718-27.

28. Kumar S, Kumar D, Kaldjian EP, Bauserman S, Raffeld M, Jaffe ES. Primary low-grade B-cell lymphoma of the dura: a mucosa associated lymphoid tissue-type lymphoma. Am J Surg Pathol. 1997;21(1):81-7.

29. Li J, Fang L, Killer HE, Flammer J, Meyer P, Neutzner A. Meningothelial cells as part of the central nervous system host defence. Biol Cell. 2013;105(7):304-15.

30. Yen MT, Bilyk JR, Wladis EJ, Bradley EA, Mawn LA. Treatments for ocular adnexal lymphoma: a report by the american academy of ophthalmology. Ophthalmology. 2018;125(1):127-36.

31. Kickingereder P, Wiestler B, Sahm F, Heiland S, Roethke M, Schlemmer HP, et al. Primary central nervous system lymphoma and atypical glioblastoma: multiparametric differentiation by using diffusion-, perfusion-, and susceptibility-weighted MR imaging. Radiology. 2014;272(3):843-50.

32. Toh CH, Castillo M, Wong AM, Wei KC, Wong HF, Ng SH, et al. Primary cerebral lymphoma and glioblastoma multiforme: differences in diffusion characteristics evaluated with diffusion tensor imaging. AJNR Am J Neuroradiol. 2008;29(3):471-5.

33. Kotapka MJ, Kalia KK, Martinez AJ, Sekhar LN. Infiltration of the carotid artery by cavernous sinus meningioma. J Neurosurg. 1994:81(2):252-5.

34. Filippi CG, Edgar MA, Uluğ AM, Prowda JC, Heier LA, Zimmerman RD. Appearance of meningiomas on diffusion-weighted images: correlating diffusion constants with histopathologic findings. AJNR Am J Neuroradiol. 2001;22(1):65-72.

35. Hwang WL, Marciscano AE, Niemierko A, Kim DW, Stemmer-Rachamimov $\mathrm{AO}$, Curry WT, et al. Imaging and extent of surgical resection predict risk of meningioma recurrence better than WHO histopathological grade. Neuro Oncol. 2016;18(6):863-72.

36. Ahlawat S, Fayad LM. Imaging cellularity in benign and malignant peripheral nerve sheath tumors: utility of the "target sign" by diffusion weighted imaging. Eur J Radiol. 2018:102:195-201.

37. Bakan AA, Alkan A, Kurtcan S, Aralasmak A, Tokdemir S, Mehdi E, et al. Cavernous sinus: a comprehensive review of its anatomy, pathologic conditions, and imaging features. Clin Neuroradiol. 2015;25(2):109-25.

38. Mahalingam HV, Mani SE, Patel B, Prabhu K, Alexander M, Fatterpekar GM, et al. Imaging spectrum of cavernous sinus lesions with histopathologic correlation. Radiographics. 2019;39(3):795-819.

39. Bakhsheshian J, Zada G, Pham MH. Cavernous sinus hemangioma: rare vascular tumor of cavernous sinus. World Neurosurg. 2018;110:432-3.

\section{Publisher's Note}

Springer Nature remains neutral with regard to jurisdictional claims in published maps and institutional affiliations. 